\title{
Neo-liberal Politikaların Medya ve Kamu Hizmeti Yayıncılığına Etkisi
}

\author{
NACIYE BERIL EKŞIOĞLU SARILAR* \\ berilsarilar@gmail.com \\ ORCID ID: 0000-0001-6181-9093
}

Öz: 1970'lerde başlayan 1980'lerden sonra etkin bir şekilde varlığını hissettiren neoliberal ekonomi politikaları dünyada iktisadi ve siyasi yapıları değiştirmiştir. Enformasyon teknolojilerinin hızla ilerlediği bu dönemde daralan piyasalar ve işsizlik yatırımcıların medyaya yönelmesine neden olmuştur. İletişim devriminin yaşandiğı bu süreçte, dünyadaki ekonomik gelişmelere paralel bir düzlemde, 1980'lerden itibaren Türkiye'de de tecimsel yaynncilk anlayışı ortaya çıkmıştır. Sahiplik/mülkiyet yapısı geleneksel basın anlayışından farklı olan ticari yayıncılığın ağırlık kazandiğı bu dönemde, sermaye-iktidar ilişkisinin karmaşıklaşması nedeniyle kamu hizmeti yayın anlayışı geri plana itilmiştir. Ancak fikriözgürlüklerin demokratik bir ortamda hür ifadesini bulacağı düşünülen ticari yayıncılık, süreç içinde tekelleşme yoluna gitmiş ve kamuoyu adına beklentileri boşa çıkarmıştır. Çalışma, ticari/özel yayıncılı̆̆ın siyasal iktidara destek veren aynı zamanda iktidardan beklenti içinde olan mülkiyet yapısına; kamu hizmeti yayıncilğııın bugünkü durumuna ve kamuoyunun ifade ve bilgiye ulaşmak gibi demokratik hak ve taleplerine çözüm olup olamayacă̆ı üzerine odaklanmaktadır. Bu maksatla neo-liberal iktisadi politikalar odağa alınarak, iktidarın/egemenlerin kitle iletişim araçlarıyla ürettiği hegemonik ilişkiler eleştirel ekonomi politik bağlamda tartışılmaktadır.

Anahtar kelimeler: Eleştirel ekonomi politik, Medya, Neo-liberal politikalar, Kamu hizmeti yayıncılı̆̆

\section{Giriş̧}

Keynesçi ekonominin anlayışını benimseyen refah toplumunun kamu yayıncısı olan devletler önce düzenlemeler (regülasyon) yaparak iletişim piyasasının aktörü olmuştur. İlerleyen dönemlerde neo-liberal politikaları benimseyen devletler, düşürülen ücretler ve sendikasızlaştırma gibi emek/sermaye dengesizliğine yol açan uygulamalarla ve deregülasyon politikalarıyla piyasaları kuralsız ve denetimsiz hale getirmiştir. ${ }^{1}$ Özelleştirme desteklenirken; medyada tekelleşmeyi, tarafsızlığı denetleyen düzenlemeler ortadan kaldırılmıștır. Yasaların ortadan kaldırılması, devletin ifade

\footnotetext{
* Dr. Öğr. Üyesi, İstanbul Aydın Üniversitesi, İletişim Fakültesi, Televizyon Haberciliği ve Programcılığı Bölümü. 1 Levent Yaylagül, “Eleştirel Ekonomi Politik Perspektiften Devlet ve Medya İlişkisi”, Maltepe Üniversitesi İletişim Fakültesi Dergisi, 5/2 (2019).
} 
özgürlüğünden elini çekmesi olarak topluma sunulmuştur. ${ }^{2}$ Dahası iletişim sektöründeki özelleştirme politikaları, neo-liberal anlayış tarafından öne sürülen çoğulculuk, çok seslilik ve özgürlük kavramlarıyla gerçekleştirilmiştir. Ancak 1980'den sonra yayıncılık sektörü kamu faydasından uzaklaşarak, egemen sınıfların çıkarlarına hizmet eder hale gelmiştir. Her bireyin demokratik bir ortamda kendini ifade etme ve kamuoyunu ilgilendiren bilgilere ulaşma hakkından yola çıkarak bugün dünya yeniden bağımsız, kamuya gerçekten hizmet eden yayıncılık anlayışının nasıl elde edilebileceğini tartışmaya açmıştır.

Gramsci, egemenlerin/iktidarın toplum düzeyinde meşruiyetini korumak için halkın desteğini almaya çalıştığını söyler. Bu çabayı rıza kavramıyla açıklayan Gramsci, rızaya dayalı egemenlik ve bağımlılık ilişkisini de hegemonik ilişki şeklinde tanımlar. Gramsci'ye göre asker, polis vb. egemenlik ilişkilerinde kullanılan zor uygulayıcı kurumlar, modern toplumlarda artık yerini rızaya dayalı hegemonyaya bırakmıştır. Egemen kesimler toplumun bağımlı kesimleri üzerinde hegemonik ilişkilerin kurulması için kitle iletişim araçlarını kullanırlar. ${ }^{3}$

Özetle hegemonya kavramı toplumdaki kültürel üretimin egemen sınıfların çıkarlarına göre yapıldığını anlatmaktadır. ${ }^{4} \mathrm{Bu}$ makalede hegemonya toplumda ortak bir anlayışla rızaya dayalı oluşturulan siyasi egemenlik bağlamında ele alınmıştır. Çalışmada neo-liberalizmle, devlet medya arasındaki ilişki eleştirel ekonomi politik ekseninde incelenmiştir. Türkiye'de 1980'lerden itibaren yayıncılık anlayışı, egemenlerin etkisi altındaki medyanın tarihsel dönüşümü kısaca ana hatlarıyla aktarılmıştır. Bu süreçte kamuoyuna hizmet anlayışından farklı bir yöne savrulan kamu yayıncısı Türkiye Radyo ve Televizyon Kurumu (TRT) ile dünyadaki farklı kamu yayıncısı kuruluşların yapılarına değinilmiştir.

Bu minvalde 1980'lerle birlikte ortaya çıkan neo-liberal politikalar çerçevesinde devletin tekelci yayın anlayışı eleştirilerek serbest pazar anlayışı çözüm olarak sunulmuştur. Ancak bugün gelinen noktada serbest piyasanın da tekelci zihniyete büründüğü gözlenmektedir. Makalede kamu yayıncısı TRT’nin kamuya hizmet/fayda şiarıyla yayıncılık yapmasının önündeki engeller tartışılmıştır.

Öncelikle makalede kullanılan terminoloji üzerinde bazı saptamalarda bulunmak gerekmektedir. Kamu hizmeti yayıncılığı kavramı farklı düşün çevrelerinde farklı anlamlara sahiptir. Bir grup bu kavramla devlet tekelinde yayıncılık yapan kuruluşları ifade ederken, bir başka grup kamu hizmeti yayıncılığını bir sistem özeti olarak kavramaktadır. Buna göre birçok Avrupa ülkesinde olduğu gibi yayıncı özel, tecimsel bir kuruluş da olsa tabi olduğu yasal düzenleme gereğiyle kamu hizmeti vermek zorundadır. Dolayısıyla makalede terimsel birliği sağlamak adına devletin mülkiyetindeki kurumlar "kamu yayıncısı" olarak; özel, tecimsel veya kamu yayıncısı olsun, demokrasinin gerektirdiği çoğulculuğu, tarafsızlığı, doğruluğu, eş zamanlılı̆̆1 göz

2 İrfan Erdoğan ve Korkmaz Alemdar, Öteki Kuram Kitle İletişim Kuram ve Araştırmalarının Tarihsel Eleştirel Bir Değerlendirmesi, Ankara: Pozitif Matbaacılık, 2010, s.405.

3 Nazife Güngör, İletişim Kuramlar ve Yaklaşımlar, Ankara: Siyasal Kitabevi, 2011, s.293.

4 Ashley Schram vd., "Media and Neoliberal Hegemony: Canadian Newspaper Coverage of the Trans-Pacific Partnership Agreement", Studies in Political Economy, 16/97 (2016). 
önüne alarak yapılan yayıncılık ise kamu hizmeti yayıncılığı olarak ele alınmıştır. Nitekim aynı gerekçeyle İngiliz yayın sisteminde de kamu yayıncısı ile kamu hizmeti yayıncısı kavramları ayrı ayrı değerlendirilmektedir.

Sosyal bilimlerde araştırmalarda bir başvuru aracı olarak derinlemesine mülakat: açık uçlu sorulara ve birebir görüşülerek bilgi toplanmasına firsat veren bir yöntem olarak kullanılmaktadır. Mülakat yapılanın bilgi, tecrübe, duygu ve gözlemlerine dayanması nedeniyle bu makalede derinlemesine mülakat yöntemi kullanılmıştır. Görüşme yapılan gazeteciler üçlü saç ayağına oturtulmuş; TRT'de uzun yıllar çalışmış ve sendikal ayağında rol almış gazeteci; dünyada birçok kamu yayıncısı kuruluşta çalışmış gazeteci ve Türkiye'de özel televizyonların haber yapısında uzun süre tepe yöneticiliği yapmış gazeteci olmak üzere üç gazeteci ile derinlemesine mülakat gerçekleştirilmiştir: TRT eski muhabiri, kamuda örgütlü Haber-Sen Sendikası (Basın Yayın İletişim ve Posta Emekçileri Sendikası) eski ilçe başkanlarından akademisyen Engin Başçı; Hollanda, Fransa, İngiltere, Türkiye, Amerika'da gazetecilik yapmış, AFP ve BBC gibi kamu yayıncısı kurumlarda çalışmış, hukukçu akademisyen Ragıp Duran ve Türkiye'de iletişim dalında özel sektöre ait yayın kuruluşlarında (Kanal D, CNN Türk) genel yayın yönetmenliği yapmış gazeteci Süleyman Sarılar.

\section{Medyanın Ekonomi Politik Yaklaşımında Teorik Arka Plan}

Hegemonik neo-liberal düzenin oluşturulması ve sürdürülmesinde medyanın rolü uzun zamandır sorgulanmakta ve tartışılmaktadır. İtalyan düşünür Antonio Gramsci "hegemonya" kavramıla toplumdaki kültürel üretimin önemini vurgular ve bu üretimi toplumdaki egemen sınıfların çıkarlarına bağlar. ${ }^{5}$ Buna göre kamuoyu adına halkın doğru bilgilenmesinden ve devletin organlarının denetiminden mesul, dördüncü kuvvet olarak tanımlanan medyanın, halk ve devlet/iktidar arasındaki gönüllü rızanın oluşmasına destek verdiği öne sürülmektedir. Fransız düşünür Louis Althusser'e göre devlet güç sahibi olabilmek için asker, polis, yargi gibi doğrudan baskı aygıtlarını kullanmaktadır. Althusser "devletin ideolojik aygıtları" kavramıyla, devletin ideoloji üretiminde de okul, din, aile, kitle iletişim araçlarını kullandığını anlatmaktadır. ${ }^{6}$ Medya, rızaya ve uzlaşmaya dayalı olarak siyasal seçkinlerin kamuoyu üzerinde hegemonik tahakküm kurması için "devletin ideolojik aygıtı" olarak işlev görmektedir.7

Kitle iletişim araçlarının "gündem belirleme" ve politik tartışmaları "çerçeveleme yeteneği", egemenlerin her zaman dikkatini çekmiştir. İktidarların kamuoyu üzerinde kurmaya çalıştı̆̆ hegemonik tahakküm açısından, haber medyasının gündemi belirleme gücü -haber medyasının belirli konulara verdiği önemi vurgulama ya da kamuoyunun bilgilenmesi gereken konuları görmezden gelebilmesi - kitle iletişim araçlarının ideolojik aygıt olarak kullanılmasına neden olmuştur. Erwing Goffman’ın haber çerçeveleme kuramına göre, gerçeğe dokunmadan, habercinin okuyucunun al-

5 Schram vd., "Media and Neoliberal".

6 Güngör, İletişim Kuramlar, s.195.

7 Süleyman İrvan, “Demokratik Sistemde Medyanın Rolü”, Birikim, 68-69 (1995), s.76. 
g1sını değiştirebileceği ${ }^{8}$ öngörüsü iktidarın siyasi ve ideolojik amaçlar için gazetecilik uygulamalarına müdahale etme eğilimlerini artırmaktadır. Özetle, kitle iletişim araçlarının haberlere yaptığı vurgu ya da görmezlikten gelme eğilimi medyaya güçlü bir ayrıcalık tanımaktadır. Bu yüzden siyasal iktidarın mevcut düzeni meşrulaştırması bakımından medya, süreç içinde çok önemli bir ideolojik araç haline gelmiştir. Bu bağlamda iki farklı ekonomi politik yaklaşım söz konusudur: pozitivist-deneysel metodolojiyi benimseyen ve bunu iletişim alanında fayda, arz, talep, fiyat gibi değerler üzerinden inceleyen, izleyici/okuyucuyu müşteri/tüketici gibi değerlendiren liberal ekonomi politik; diğeriyse iktidar, sınıf, ideoloji çatışmaları üzerinden siyasal ekonomiyi okuyan eleştirel ekonomi politik paradigmadır. Liberal ekonomi politik yaklaşım, serbest pazar içindeki seçeneklerin artışı, halkın seçme özgürlüğünün artması, devletin serbest pazarı düzenlemedeki rolü, özelleștirme uygulamaları ile ilgilenir. ${ }^{9}$ Bu nedenle 1970’lerdeki iletişim çalışmalarında medya, sınıf egemenliği bağlamında ele alınmış, sınıf tahakkümü kavramı kullanılmaya başlanmıştır. ${ }^{10}$ Eleştirel yaklaşım kitle iletişim alanındaki sahiplik yapısını, iktidarın rolünü, tekelleşme eğilimlerini ve haberin metalaşma sürecini irdeler. Levent Yaylagül, eleştirel ekonomi politik yaklaşımla ilgili şunu vurgulamaktadır:

$\mathrm{Bu}$ yaklaşım olumsuz ve yıkıcı değil aksine özgürleştiricidir. Bu yaklaşımın amacı, insanlara iktidar tarafından nasıl yönlendirildiğini göstererek, aydınlatılmasıdır. Bu anlayış küreselleşme, mülkiyet biçiminde yoğunlaşma (tekelleşme) gibi geniş kapsamlı konularda çalışır ve dünyaya bir bütün içerisinde bakar, onu anlar ve eleştirir. ${ }^{11}$

Karl Marx ve Friedrich Engels'in ortak çalışması 1845 tarihli Alman İdeolojisìnde; "Egemen sınıfin düşünceleri, bütün çağlarda egemen düşüncelerdir. Başka bir deyişle toplumun egemen gücü olan sınıf aynı zamanda zihinsel güçtür. Maddi üretim araçlarını elinde bulunduran sınıf, zihinsel üretim araçlarını da emrinde bulundurur"12 saptaması yapılmış; Karl Marx 1859 tarihinde kaleme aldığı Ekonomi Politiğin Eleştirisi adlı eserde ise "kültürel üretimin analizi için sınıf temelli yaklaşımın yeterli olmadığını, ekonomik bağlamın da incelenmesi gerektiği”"13 kanaatini ortaya koymuştur.

Eleştirel ekonomi politik, kıta Avrupa'sında ve Amerika'daki sosyal bilimciler arasında farklı yaklaşımlarla ele alınmıştır. Eleştirel ekonomi politik paradigma sınıf mücadelesi ve kapitalist devlet kavramları çerçevesinde Amerika'da araçsalcı, Avrupa'da yapısalcı anlayışa odaklanır. Amerika'daki araçsalcı yaklaşıma göre devlet kapitalist sınıfın çıkarları doğrultusunda hareket eder. Amerikalı eleştirel ekonomi politikçiler, "zihin yönlendirme ve propaganda teknikleri" ile kapitalizmin sorunlarının kamuoyundan gizlendiğini öne sürerler. Avrupa’daki eleştirel ekonomi politikçiler ise med-

8 Schram vd., "Media and Neoliberal".

9 Peter Golding ve Graham Murdock, "Kültür, İletişim ve Ekonomi Politik”, çev. Beybin Kejanlığlu, Medya, Kültür, Siyaset, der., Süleyman İrvan, Ankara: Pharmakon Yayınevi, 2014, s.53-54

10 Erdoğan ve Alemdar, Öteki Kuram, s.214.

11 Yaylagül, "Eleştirel Ekonomi”, s.134-152.

12 Gülseren Adakl1, Türkiye’de Medya Endüstrisi, Ankara: Ütopya Yayınevi, 2006, s.24.

13 Karl Marx ve Friedrich Engels, Alman İdeolojisi, çev., Sevim Belli, Ankara: Sol Yayınları, 2004, s.75. 
yanın bütüncül/yapısal olarak nasıl işlediğini ve küresel medya ağıyla nasıl mücadele edeceğine odaklanırlar. Avrupa’da ekonomi politik çalışmalar sömüren-sömürülen üzerinden düalist bir felsefeyle iki kutuplu bir dünya üzerine oturtulur. ${ }^{14} \mathrm{Bu}$ nedenle araçsalcı yaklaşım kapitalist sınıfın medyayı kamuoyu üzerindeki bir kontrol aracı olarak kullandığını ve medya sahipliği yapısının bunu belirlediğini öne sürer. Fransız düşünür Louis Althusser'den yola çıkan yapısalcı yaklaşım ise kapitalist ekonominin medyanın stratejilerini belirlediğini ve bu sayede medyanın kapitalist sınıfın diğer sınıflar üzerinde tahakküm kurmasına aracılık ettiğini öne sürer. Dolayısıyla her iki yaklaşımda da devletin özerkliği kapitalist sınıfın menfaatleri doğrultusunda sınırlandırılmaktadır. Zira devlet, kapitalist sınıf egemenliğinin meşrulaştırılması ve yeniden üretilmesinin bir aracıdır.

Araçsalcı yaklaşımın önemli düşünürlerinden Noam Chomsky ve Edward Herman tarafindan kaleme alınan Medya ve Propaganda Modeli adlı eserde, medyadaki servet ve güç eşitsizliği ile bu eşitsizliğin kitle medyasındaki etkilerine odaklanılmaktadır. Buna göre kitle iletişim araçlarını elinde bulunduran ve iktidarla yakın ilişki içinde olan sermaye, siyasi ve ekonomik menfaatler doğrultusunda kamuoyuna neyin duyurulup duyurulmayacağına önceden karar vermektedirler. Böylece totaliter rejimlerde zor kullanılarak kurulan tahakküm, demokratik toplumlarda güç yerine r1zanın imalatı, gönüllü katılım ve propaganda aracılığıyla kurulmaktadır. ${ }^{15}$ Chomsky ve Herman'a göre medya, kamuoyunun bilgisine sunulması gereken önemli haberler yerine, gündemi meşgul eden sıradan haberlere yer vermektedir. Medyanın nesnellikten uzaklaşmasına neden olan beş faktörden (süzgeçten) biri "kitle medyasının mülkiyetçi, kar odaklı yapısı ve medyaya yaptırım uygulayan kurumlar”16 olarak gösterilmektedir.

\section{Neo-liberal Politikalarla Türk Medyasında Değişen Patronaj Yapısı}

İletişim sektöründeki gelişmeler aslında dünyada genel ekonomik politikalarla paraleldir. 1929'daki buhran yılları ile başlayan finans piyasalarındaki çöküş, takip eden yıllarda şirketlerin tekelleşmesine neden olduğu gibi İkinci Dünya Savaşı’nın ardından yeni bir ekonomik anlayışın kapılarını aralamıştır. Buhrandan çıkış reçetesi olarak gösterilen Keynesyen ekonomi yaklaşımı ile devlet, kamu yararı kavramını ön plana almış ve karma bir ekonomik yapı içerisinde kısmen de olsa ekonomiye müdahale etme hakkını meşrulaştırmıştır. Özellikle Avrupa ülkelerinde devlet, kamu yayıncılığg girişimleriyle iletişim sektöründe aktif bir rol üstlenmiştir. Kamu yayınc1larının bütçesi devletin kasasından karşılanırken; yayın ilkeleri, denetimi, çoğulculuk anlayışı da yine devletin garantisi altındadır. Bu durum 1980'lerde hız kazanacak neo-liberal politikalarla refah devleti kavramı sorgulanana kadar devam etmiştir. Dolayısıyla neo-liberalizm, serbest piyasada devletin düzenleyici rolünü öngören Keynesyen iktisadı bertaraf etmiştir. ${ }^{17}$

14 Yaylagül, "Eleştirel Ekonomi”.

15 Bahar Muratoğlu, “Bir Demokrasi Masalı: Özgür Birey, Bağımsız Medya”, Pivolka, 20/6 (2011).

16 Edward S. Herman ve Noam Chomsky, Rızanın Imalatı: Kitle Medyasının Ekonomi Politiği, çev., Ender Abadoğlu, İstanbul: BGST Yayınları, 2006.

17 Kemal Aslan, İkna Ekranları, İstanbul: Anahtar Kitaplar Yayınevi, 2014, s.39-40. 
Klasik liberalizm birey hak ve özgürlükleri ön plana çıkarırken; 1980'li yıllarla birlikte küresel düzlemde egemen olan neo-liberalizm, ekonomik özgürlüklere odaklanmış, sermaye ve emek arasındaki güç ilişkilerini sermaye lehine kullanan bir sınıf politikası ortaya koymuştur. ${ }^{18}$ Neo-liberal politikaya göre devlet iletişim sektörünün önündeki bir engel olarak görülür, bu yüzden kamudaki yayın tekelinin ortadan kaldırılması hedeflenmiştir. Bu dönemde devletin müdahalesi tümüyle ortadan kalkmamış sadece yön değiştirmiştir: devletin rolü neo-liberal yapıda artık yeni piyasa şartlarını oluşturmaktır. ${ }^{19}$ Buna göre, devletin sağlık ve iletişim gibi konularda üstlendiği harcamalar azaltılmış ve kamu işletmeleri özelleştirme programı içine alınmıştır. İngiltere'de dönemin Başbakanı Margaret Thatcher ile başlayan özelleştirme programı, Türkiye dâhil tüm üçüncü dünya ülkelerine kısa süre içinde yayılmıştır. Böylece buhran sonrası yıllardan itibaren öne sürülen refah devleti ve kamu hizmeti anlayışı ihmal edilerek; kapitalist sermaye tarafından her firsatta seslendirilen sosyal sorumluluk ve çoğulculuk sloganları kullanılarak özgürlük ve seçme şansı vaat edilmiştir. $^{20}$

1980 'lerden itibaren genişleyen uluslararası pazarın etkisiyle özelleştirme ve deregülasyon politikaları küresel mahiyette güç kazanmıştır. Özelleştirme ile kamu mülkiyetine tabi şirketler, birer ikişer elden çıkarılıp özel sektörün mülkiyetine bırakılmış ve "deregülasyon" ile yasal düzenlemeler kaldırılmıştır. ${ }^{21}$ Sağın ideolojik temelini oluşturan neo-liberalizm ile tüm sektörlerde olduğu gibi devletin elindeki kamu yayıncıllğı hizmetinde de özelleştirme yoluna gidilmiştir. Sadakaoğlu’na göre:

Türkiye’de iktidarın söylem üretme gücü; birinci yapısal dönüşüm dönemi olarak adlandırılan $80^{\prime}$ li yılların siyasal, ekonomik ve gündelik yaşam pratiklerinin biçimlendirildiği bir dönemin bütünselliğine tekabül eder. Dönüşümü yürüten başta siyasal özne ve kurumlar ile medyadan yayımlanan temsiller tarafından dile getirildiği şekliyle çağ atlama söylemi etrafında kümelenmiştir. Ancak dönemin kuşatıcı siyasal atmosferi içinde idrak edildiği biçimiyle bu söylem basitçe değişim telkin eden bir seçenek olmakla kalmayarak, kıyas kabul etmez bir zorunluluk olarak sunulmaktadır. ${ }^{22}$

Bu minvalde 1980'li yıllardan itibaren liberal çevreler, medyanın devlet ya da siyasal iktidara olan mesafesini ancak finansal anlamda bağımsız olmasıyla mümkün olacağ 1 şeklindeki etkili söylem üzerinden tescil etmiştir. Dolayısıyla medyanın bağımsızlık söyleminde vurgulanan esas nokta dördüncü kuvvet rolünün teminatıdır. Ancak 1980 'lerden itibaren hayata geçirilen uygulamalara bakıldığında medya ve bağımsızlık arasındaki ilişkinin iyi niyetli bir temenni olmaktan öteye geçemediği görülmektedir. Neo-liberal politikaları Türkiyéde 24 Ocak Kararlarıyla birlikte, dönemin Başbakan Yardımcısı Turgut Özal uygulamaya koymuştur. Feroz Ahmad’a göre, 24 Ocak

18 Aslan, İkna Ekranlarl, s.43-44.

19 Adakl, Türkiye'de Medya, s.39.

20 Erdoğan ve Korkmaz, Öteki Kuram, s.402.

21 Yaylagül, "Eleștirel Ekonomi", s.144-145.

22 Mustafa C. Sadakaoğlu, "Yeni Türk Sinemasında Modern Melodram Geleneksel Söylem", Motif Akademi Halkbilimi Dergisi, 12/28 (2019), s.1191. 
Kararlarına giden yolda 1980 darbesinin iki rolü bulunmaktadır: muhalefetin olmadığı ve toplumun depolitize edildiği sükûnet ortamında yeni bir siyasal yapılanmayı yaratmak çok daha kolayd..$^{23}$ Özal, piyasa ekonomisine geçişle IMF’nin Türkiye’ye sunduğu istikrar paketinin uygulanmasını kolaylaştırmıştır. 24 Ocak Kararlarıyla ithal ikameci ekonomi politikalarından serbest piyasa kurallarına geçiş ile birlikte devlet tarafından gazete kâğıdına uygulanan sübvansiyonlar kaldırılmıştır. Kısıtlanan bütçe nedeniyle yazılı basında haber takibi masa başından yapılmaya başlanmış, köşe yazarlarının haber kaynakları ile doğrudan ilişki kurmaya başlaması muhabirlerin haber yapım sürecindeki işlevinin gerilemesine neden olmuştur. Bu ortamda muhabirler yaptıkları işe yabancılaşmış, temel gazetecilik ilke ve değerleri aşınmaya başlamıştır. Gazetecilik, gazete sahiplerinin kar oranlarını takip eden yayıncılık anlayışıyla yer değiştirmiştir. Reklam ve ilan geliri elde edebilen siyasal bağları güçlü gazeteler, yeni koşullarda ayakta kalmaya çalışan irili ufaklı gazeteleri satın almış ya da çekilmeye zorlamış, böylece büyük gruplardan oluşan tekelci yayıncılığın kapıları aralanmıştır. ${ }^{24}$ Bu durum Turgut Özal tarafından "ülkede iki buçuk gazeteden fazlasına gerek yok" ${ }^{25}$ şeklinde ifade edilmiş, gazete yayıncılığ 1 tekelleşme içine girmiştir. Kamu yararını gözetmekle sorumlu gazetecilik anlayışı gerileyerek demokrasi kültürünü akamete uğratmıştır. ${ }^{26}$

1990’lı yıllarda gazete sahipliğinin gazetecilik dışında pek çok alanda faaliyet gösteren büyük holdinglerin parçası haline gelmesi, medyanın yeni mülkiyet ilişkileri dahilinde yozlaşmasına neden olurken, medya ile iktidar arasında "kredi, borç öteleme ve kamu ilanlarıyla destek" benzeri karmaşı ilişkilerin kurulmasına neden oldu. Dolayısıyla geçmişte ilan ve reklam aracılığıyla medyada etki yaratmaya çalışan holdingler, yeni mülkiyet anlayışı ve yatay yoğunlaşma içine girerek çok daha kestirme bir yol üzerinden gazete sahibi olmaya başladılar. Bu dönemde gazetelerin genel yayın yönetmenleri gazete sahiplerinin ticari işlerini kovalayan aktörler haline gelmiştir.

1980’lerde sermayenin hızla üretimden çekilip finans sektörüne yönelmesiyle Türkiye'de "rantiye" olarak tanımlanan toplumsal bir katman oluşmuştu. 24 Ocak politikalarıyla da finans piyasasına ilişkin alınan kararlar medya sektörünün bankacılık alanına yönelmesine neden olmuştur. Öyle ki 1990’larda medya sahipleri bir veya birkaç bankanın sahibi konumundaydılar: Star TV ve Star gazetesine sahip Uzan Grubuna ait Adabank, İmar Bankası; Milliyet ve Yeni Yüzyıl gazetelerine sahip Korkmaz Yiğit’e ait Bank Ekspress; Zaman gazetesi ve STV’nin sahibi Fethullah Gülen'e ait Asya Finans; Hürriyet, Tempo, Kanal D, CNNTürk ü̈n sahibi Doğan Grubuna ait Dışbank; Sabah Grubuna ait Etibank; NTV’nin sahibi Doğuş Grubuna ait Körfezbank, Garanti Bankası; TV8'in sahibi MNG'e ait MNG Bank; Cine 5'in sahibi Erol Aksoy’a ait İktisat Bankası; Olay TV’nin sahibi Nergis Holding’e ait İnterbank medya

23 Feroz Ahmad, Demokrasi Sürecinde Türkiye (1945-1980), çev. Ahmet Fethi, İstanbul: Hil Yayınları, 1994. 24 Atilla Özsever, “Demokrasi Sürecinde”, s.151-152.

25 Tavsife Selen, “Çok Gazete Çok Bilgi Değilmiş Meğer!”, Bianet, 18.01.2003, http://bianet.org/bianet/ print/16059-cok-gazete-cok-bilgi-degilmis-meger.

26 Savaş Çoban, Hegemonya Aracı ve İdeolojik Aygıt Olarak Medya, İstanbul: Parşömen Yayıncılık, 2013, s.184. 
sektöründeki banka/finans kuruluşlarıydılar. ${ }^{27}$ Medyada oligopolistik yapının getirdiği yıkıcı rekabet ortamları, medya sahiplerinin banka satın almaları, promosyon dönemlerinin yükselttiği maliyetlerin haber kadrolarını küçültmesi, Türk basınında sendikaların tasfiyesi, özel televizyonların açılması bu dönemin neo-liberal politikalarının medyaya yansımalarıdır. Bu dönemde gazetelerde sayıca artan köşe yazarları ise serbest pazar ekonomisin taşıyıcları ve yeniden üreticileri olarak tanımlanmış$\operatorname{tir}^{28}$

1998'de Kanal 6’yı Turgut Özal'ın oğlu Ahmet Özal'dan alan, Milliyet ve Yeni Yüzyıl gazetelerini de alarak müteahhitliğin ardından medya sektörüne giren iş adamı Korkmaz Yiğit’in adının karıştığı Türkbank skandalı 55. Hükümetin düşmesine yol açmıştır. ${ }^{29}$ 1990'ların sonundan itibaren TMSF'ye devredilen bankalardan Egebank, Yurtbank, Yaşarbank, İnterbank, Esbank, İktisat Bankası, Kentbank, EGS Bank, Etibank, Toprakbank başka bankalarla birleştirilmiş; Bank Ekspres, Demirbank, Sümerbank, Sitebank, Tarişbank satılmış; Türk Ticaret Bankası, Bayındırbank ve Pamukbank da yine tasfiye sürecinden geçen, TMSF (Tasarruf Mevduatı Sigorta Fonu) bünyesine katılan bankalardır. ${ }^{30}$ TMSF 2001 yılında büyük medya şirketlerinin iflas etmesiyle (kriz medyada yoğun oranda işsizliğe neden olmuştur) sektördeki bu şirketlere el koymuş, dolayısıyla siyasal iktidar medya sektöründe büyük pay sahibi olmuştur. 2013 yllında ise 11 medya grubu iktidara yakın iş insanlarına satılmıştır. ${ }^{31}$ Engin Baş̧̧ı tarafindan süreç şöyle değerlendirilmektedir:

Medya şirketlerine kayyumların atanması finansal nedenlerleydi, ancak bu dönemde kurumların içine gazeteci olmayan kişiler getirildi. Oysa gazeteci kadrosunun değiștirilmemesi gerekiyordu. Daha sonra devletten kamu ihalesi alan inşaat, enerji sektöründeki şirketlere bu medya yapıları aldırıldı. ${ }^{32}$

Türk medyasında yatay (aynı pazarda faaliyet gösteren şirketlerin tek bir çatı altında birleşmesi), dikey tekelleşmeye (aynı sektörde farklı ürün veya hizmetlerde tekelleşmek) ve çapraz bütünleşmeye (farklı sektörlerdeki şirketlerin mülkiyetinin tek bir elde toplanmasına -medya, enerji, bankacılık vs. gibi) sıkça rastlanmaya başladı. $\mathrm{Bu}$ durumun aşağıdaki tablolardaki verilerden yola çıkarak günümüzde de devam ettiği görülmektedir: Medya Sahipliği İnceleme Projesi kısa adıyla MOM (Media Ownership Monitor), 2018 yılında Türkiye’de 40 medya kuruluşunu incelemiştir. Basın yayın organlarındaki yatay yoğunlaşmanın verildiği aşağıdaki tabloda, bu durumun kamuoyu açısından oluşturduğu risk de belirtilmektedir. Aynı ülkede faaliyette bulunan en büyük dört şirketin toplam takipçi/izleyici/okur/dinleyici payı \%50'nin üzerinde ise yüksek derecede risk, \%25-\%49 ise orta derecede risk, \%25’in altında ise düşük derecede risk oluşturmaktadır. Bu çalışmayla sektörde yüksek yatay sahiplik yoğunlaşmasına karşı (sektöre özel) düzenlemelerin varlığını, yasa ve düzenlemelerin uy-

27 Adakl1, Türkiye'de Medya, s.212-215.

28 Adakl, Türkiye'de Medya, s.308.

29 Adakl1, Türkiye'de Medya, s.308.

30 Adakl1, Türkiye'de Medya, s.377-379.

31 "Medya ve Siyaset”, erişim 17 Ağustos, 2020, https://turkey.mom-rsf.org/tr/.

32 N. Beril Ekşioğlu Sarılar, Engin Başçı ile mülakat, 21.07.2020. 
gun denetleme ve yaptırım sistemi sağlayıp sağlamadığı ölçmek amaçlanmıştır.

Tablo 1. Türkiye'de Basın Yayın Organlarına Göre "Yatay Yoğunlaşma Oranları" (Sermaye sahibinin birden fazla bağımsız yayın organına sahip olmasi) ve kamuoyu açısından risk düzeyleri verilmiştir ${ }^{33}$

\begin{tabular}{|l|l|l|}
\hline Basın Yayın Organları & Yatay Yoğunlaşma Oranı & Kamuoyu Açısından Risk Düzeyi \\
\hline Yazılı Basın & $\% 60$ & Yüksek Risk \\
\hline İnternet (Çevrimiçi) & $\% 83$ & Yüksek Risk \\
\hline Radyo ve Televizyon & $\% 40-44$ & Orta Derecede Risk \\
\hline
\end{tabular}

Türkiye'de faaliyet gösteren takipçi, izleyici, okur ya da dinleyici sayısı en fazla 10 şirket incelenmiş ve iktidarla olan bağı analiz edilmiştir. Bu oran tablo 2'de gösterilmektedir. Tablo 3'te ise iktidara yakın medyaların takipçi, okur, dinleyici ya da izleyici oranları verilmektedir.

Tablo 2. Türkiye'de Okuyucusu/Dinleyicisi/Takipçisi/İzleyicisi En Çok Olan İlk 10 Kurumdan İktidara Yakın İçerik Üretenlerin Oranı ${ }^{34}$

\begin{tabular}{|l|l|}
\hline $\begin{array}{l}\text { Okuyucusu/Dinleyicisi/Takipçisi/İzleyicisi En } \\
\text { Çok Olan İlk 10 Medya Kurumu }\end{array}$ & Íktidara Yakın İçerik Üretenlerin Oranı \\
\hline En Yüksek Tirajlı 10 Gazeteden & $\begin{array}{l}\text { 9’u (Sözcü Gazetesi hariç) siyasal iktidara } \\
\text { yakın haber yapıyor. }\end{array}$ \\
\hline En Çok Dinlenen 10 Radyo Kanalının & 10’u siyasal iktidara yakın haber yapıyor. \\
\hline En Çok İzlenen 10 Televizyon Kanalının & $\begin{array}{l}\text { 9'u (Fox Televizyon Kanalı hariç) siyasal } \\
\text { iktidara yakın haber yapıyor. }\end{array}$ \\
\hline $\begin{array}{l}\text { En Çok Tekil Ziyaretçi Sayısına Sahip 10 } \\
\text { Dijital Haber Portalından }\end{array}$ & $\begin{array}{l}\text { 7’si (cumhuriyet.com.tr; sözcü.com.tr; } \\
\text { memurlar.net hariç) siyasal iktidara yakın } \\
\text { haber yapıyor. }\end{array}$ \\
\hline
\end{tabular}

Üst tablodaki verilere göre; en yüksek tirajlı 10 gazeteden 9'u, en çok dinlenen 10 radyo kanalı, en çok izlenen 10 televizyon kanalından 9'u ve en çok tıklanan 10 internet haber sitesinden 7'si iktidarla yakın ilişki içinde olan medya gruplarına aittir.

Tablo 3. İktidara/Hükümete Yakın Medyaların Yoğunlaşma Oranları ve Sağlıklı Bir Kamuoyunun Oluşması Açısından İçerdiği Risk Düzeyleri ${ }^{35}$

\begin{tabular}{|l|l|l|}
\hline $\begin{array}{l}\text { Basın Yayın } \\
\text { Kuruluşları }\end{array}$ & $\begin{array}{l}\text { İktidara Yakın Medyaların Yoğunlaşma } \\
\text { Oranları }\end{array}$ & $\begin{array}{l}\text { Sağlıklı Bir Kamuoyu } \\
\text { Açısından Yarattığı Risk } \\
\text { Düzeyi }\end{array}$ \\
\hline $\begin{array}{l}\text { Televizyon } \\
\text { İzleyicilerinin }\end{array}$ & $\begin{array}{l}\text { \%44 ü (Turkuaz \%16, Demirören \%9, } \\
\text { TRT \%11, Doğuş \%8) }\end{array}$ & Orta Derecede Risk \\
\hline
\end{tabular}

33 "Medya ve Siyaset".

34 "Medya ve Siyaset".

35 MOM bu araştırma için Televizyon İzleme Araştırmaları Şirketi (TİAK), Basın İlan Kurumu (BİK), Ulusal Radyo Yayıncıları Derneği (URYAD) ve Gemius Turkey’ den elde edilen verileri esas almıştır bkz. "Medya ve Siyaset". 


\begin{tabular}{|l|l|l|}
\hline $\begin{array}{l}\text { Çevrimiçi Haber } \\
\text { Sitelerinin }\end{array}$ & $\begin{array}{l}\text { \%73’ü (Demirören Grubu hariç) Turkuaz } \\
\text { \%29, Ciner \%22, Hayat Görsel Yayıncılık } \\
\text { \%17, Estetik \%15) }\end{array}$ & Yüksek Derecede Risk \\
\hline Yazılı Basının & $\begin{array}{l}\text { \%60'ı (Demirören Grubu \%23, Turkuaz } \\
\% 15, \text { Türk Medya \%12, Estetik \%10) }\end{array}$ & Yüksek Derecede Risk \\
\hline Radyoların & $\begin{array}{l}\text { \%42'si (Doğuş \%21, Kamu \%11, Hayat } \\
\text { Görsel Yayınclılı \%4, Show Radyo \%4) }\end{array}$ & Orta Derecede Risk \\
\hline
\end{tabular}

İktidara yakın medya organlarının yoğunlaşmasını gazeteci Süleyman Sarılar şöyle değerlendirmektedir: "Demokrasi kültürünün kökleşmesine aracı olan basın-yayın organları iktidarın kontrol ettiği bir medya halini aldığında, tam tersine demokrasinin ayak bağ 1 haline gelmekte ve kamuoyuna zarar vermektedir." ${ }^{36}$

Medyadaki daralma ve iktidar-medya bağlantısı günümüzde de devam etmektedir. Aşağıda Tablo 4'te yayın hayatını sürdüren üç büyük medya grubunun sektördeki ve medya dışındaki faaliyet alanları ve aldıkları bazı kamu ihaleleri gösterilmektedir.

Tablo 4. Türkiye'de Faaliyet Gösteren 3 Büyük Ulusal Medya Kuruluşunun Basın Yayıncılık ve Medya Harici Faaliyet Alanları ${ }^{37}$

\begin{tabular}{|c|c|c|}
\hline Medya Grubu & Basın Yayıncılık Faaliyetleri & Faaliyet Gösterdiği Alanlar \\
\hline $\begin{array}{l}\text { Demirören } \\
\text { Medya Grubu }\end{array}$ & $\begin{array}{l}\text { Gazeteler: Milliyet, Vatan, Fanatik, Hürriyet, } \\
\text { Posta, Hürriyet Daily News } \\
\text { Radyolar: CNN Türk Radyo, Radyo D } \\
\text { Televizyonlar: Cartoon Network, CNN Türk, } \\
\text { Çocuk Smart, Dream TV, Dream Türk, Kanal } \\
\text { D, NBA TV, Çocuk Smart, teve2 } \\
\text { Dijital platform: D-Smart } \\
\text { Basım: Demirören Printing Center ve } \\
\text { Hürriyet Kitap } \\
\text { Dağıtım: Yaysat } \\
\text { Online Hizmetler: milliyet.com/vatan.com } \\
\text { milliyetemlak.com } \\
\text { /fanatik.cmhurriyet.com/ } \\
\text { hurriyetdailynewscom/ } \\
\text { hurriyetaile.com/ mahmure.com/ } \\
\text { hurriyetemlak.com/ } \\
\text { hurriyetoto.com/ } \\
\text { uzmanpara.com/ ekolay.net/kanald.com/ } \\
\text { bigpara.com/ cnnturk.com } \\
\text { Haber Ajansı: Demirören Haber Ajansı } \\
\text { (DHA) Grubun Medya Takipçi Payı: \%15 }\end{array}$ & $\begin{array}{l}\text { Eğitim } \\
\text { İnşaat } \\
\text { Turizm } \\
\text { Madencilik } \\
\text { Medya } \\
\text { Şans Oyunları } \\
\text { Dijital }\end{array}$ \\
\hline
\end{tabular}

36 N. Beril Ekşioğlu Sarılar, Süleyman Sarılar ile mülakat, 21.05.2020.

37 "Medya ve Siyaset". 


\begin{tabular}{|c|c|c|}
\hline $\begin{array}{l}\text { Turkuvaz } \\
\text { Medya Grubu } \\
\text { (Kalyon } \\
\text { Grubu, Zirve } \\
\text { Holding) }\end{array}$ & $\begin{array}{l}\text { Gazeteler: Sabah (2007 TMSF’den satın aldı), } \\
\text { Takvim (2007 TMSF'den satın aldı), Yeni Asır } \\
\text { (2007 TMSF’den satın aldı, Fotomaç (2007’de } \\
\text { TMSF'den satın aldı), Daily Sabah, Sabah } \\
\text { USA, Fikriyat, Sabah Avrupa } \\
\text { Televizyonlar: atv (2007’de TMSF'den satın } \\
\text { aldı.), a Haber, Minika, Minika Çocuk a Spor, } \\
\text { a News, a Para, a News, Yeni Asır TV, atv } \\
\text { Avrupa } \\
\text { Dergiler: Bebeğim ve Biz, Cosmopolitan, } \\
\text { Esquire, Forbes Türkiye, Harper’s Bazaar, } \\
\text { HomeArt, House Beautiful, Otohaber, Para, } \\
\text { Sofra, Şamdan Plus vs. } \\
\text { Radyolar: Radyo Turkuvaz, a Haber Radyo, a } \\
\text { Spor Radyo, Vav Radyo. } \\
\text { Basım Dağıtım: Turkuvaz Maatbaacılık, } \\
\text { Turkuvaz Dağıtım, Abone Turkuvaz } \\
\text { Online yayınlar: teknokulis.com/ aktüel.com. } \\
\text { tr/turkuvazradyolar.com } \\
\text { Kitap ve Yayıncılık: Turkuvaz Kitapçllık } \\
\text { Yayıncılık Sanayi A.Ş., D\&R Kitap, İdefix } \\
\text { Kitap } \\
\text { Grubun Medya Takipçi Payı: \%30 }\end{array}$ & $\begin{array}{l}\text { İnşaat } \\
\text { Altyapı } \\
\text { Enerji } \\
\text { Kimya } \\
\text { Medya } \\
\\
\text { Aldığı bazı ihaleler: } \\
\text { İstanbul Havaalanı, } 6 \\
\text { Otoyol, Metrobüs hattı, } 2 \\
\text { Raylı sistem, Marmaray, } \\
\text { İstanbul'da } 5 \text { metro hattı, } 5 \\
\text { isale hattı, Başkent Emlak } \\
\text { Konutları, Dr, Lütfi Kırdar } \\
\text { Kartal Eğitim ve Araştırma } \\
\text { Hastanesi, Başakşehir } \\
\text { Stadyumu, Bakırköy Adalet } \\
\text { Binası, Taksim Meydan } \\
\text { Projesi, 4 HES projesi, Irak } \\
\text { Erbil Su Temini Projesi, } \\
\text { Kuzey Irak Çadır kent }\end{array}$ \\
\hline $\begin{array}{l}\text { Ciner Medya } \\
\text { Grubu }\end{array}$ & $\begin{array}{l}\text { Gazeteler: Habertürk (kapandı) } \\
\text { Televizyonlar: Habertürk TV, Bloomberg HT, } \\
\text { Show TV (TMSF'den satın aldı), Show Türk, } \\
\text { Show Max } \\
\text { Radyolar: Haber Türk Radyo, Bloomberg HT } \\
\text { Radyo } \\
\text { Matbaa:HaberTürk Matbaacıllk } \\
\text { Online yayınlar: haberturk.com, bloomberght. } \\
\text { com, showtv.com } \\
\text { Grubun Medya Takipçi Payı: \%15 }\end{array}$ & $\begin{array}{l}\text { Sanayi, Maden, Ticaret, } \\
\text { Enerji, Medya, Denizcilik, } \\
\text { Hizmet sektörü } \\
\\
\text { Aldıkları bazı ihaleler: } \\
\text { Çayırhan Termik Santrali } \\
\text { ve Silopi Termik Santrali, } \\
\text { Konya Ilgın Elektrik } \\
\text { Üretim Santrali, Havaş } \\
\text { Turizm. Turgay Ciner } \\
\text { Kasımpaşaspor'u 2011'de } \\
\text { satın aldı. }\end{array}$ \\
\hline
\end{tabular}

(Tablo 4, medya gruplarının kendi sitelerinden derlenmiş bilgilerden oluşturulmuştur).

İktidarı destekleyen holdinglerin medya alanında yoğunlaşması, gazete ve dergi tirajlarına olumsuz olarak yansımaktadır. Türkiye İstatistik Kurumu verilerine göre son 10 yılda gazete ve dergilerin tirajı yüzde 51,2 oranında azalmıştır. ${ }^{38}$ Engin Başçı tirajlardaki bu düşüşü şöyle yorumlamaktadır:

Bu düşüşte tabii ki internet medyasının, sosyal medyanın rolü var. Ulusal bazı gazeteler kapatılmış durumda, geri kalanlara da güven azaldı. Yerel gazeteler ise basın ilan kurumlarının resmi ilanları dağıtması konusunda siyasi iktidarın propaganda örgütleri gibi çalışıyor. Verilere göre ilan ve reklam oranları $\% 3$ oranında artmış belli ki iktidar yerel basını kontrol altında tutmak istiyor. ${ }^{39}$

38 “Türkiye'de Gazete ve Dergi Tirajları: 10 Yılda Yarı Yarıya Azaldı”, Journo, 20.07.2020. https://journo.com.tr/ gazete-dergi-tiraj.

39 Engin Başçı ile mülakat, 21.07.2020. 
Veriler ışığında, özel sektörün yoğunlaşmış mülkiyet yapısının iktidarın ideolojisini aktarmakta aracı olduğu ve kamu hizmetini ön planda tutabilecek tarafsızlığı ve bağımsızlı̆̆ı benimseyen bir yayın anlayışına sahip olamayacağı aşikardır. Bu durum gelişmiş bir demokrasi anlayışı için toplumun kendini ifade edebileceği ve yaşadığı çevreye ilişkin sağlıklı bilgiler alabileceği yayın organlarına olan ihtiyacı arttırmaktadir.

\section{Kamu Yayıncılığının Türkiye ve Dünyadaki İşleyişi}

Erol Mutlu’ya göre, kamu hizmeti yayıncılığı esas olarak ulus kavramıyla ilişkilendirilmelidir. ${ }^{40}$ Buna göre radyo ve televizyon yayıncılığı, ulus-devletin inşası için kültürel-siyasal araç olarak kavranmakta ve yayıncılığa özel sektörün eline bırakılamayacak denli büyük önem atfedilmektedir. ${ }^{41}$ Benzer şekilde kamu hizmeti yayıncılığı, Avrupa demokrasisinin vazgeçilmez bir unsuru olarak değerlendirilmektedir. Kamu hizmeti yayıncılığı tarafsızlık ilkesi altında eğitimi ve kültür aktarımını hedefler; çoğulculuk, kültür çeşitliliğine vurgu yapar; özerktir, bağımsızdır ve tarafsızdır. Kamu kaynakları tarafından desteklendiği için ticari yayın kuruluşları gibi reklamlar aracılığıyla gelir elde etme gibi bir zorunluluğu yoktur. Kamu hizmeti yayıncılığ1nın finansmanı kamu fonlarından, ruhsat gelirlerinden ve bandrollerden elde edilir. Kamu hizmeti yayıncılığı "halk için yapılan, halk tarafından finanse edilen ve halk tarafından kontrol edilen” yayıncılık anlayışı olarak tanımlanır. ${ }^{42}$ Dolayısıyla üç temel etik ilke üzerine oturmalıdır: idari özerklik, mali özerklik ve editoryal bağımsızlık. 1961 Anayasası ile radyo ve yayıncılığının özerk, tarafsız bir kamu kuruluşu tarafından yapılması gerekliliği belirtilmiştir. Bu hükme göre devlet tekeli vardır ve bu tekel özerk bir kamu kurumu üzerindendir. Bu madde ile siyasi çıkarların önüne geçilmek istenmiştir. Ancak 1980'lerde TRT iktidarın politikalarına destek veren bir yayın politikasına sahip olmuş, editoryal yapıya ideolojik müdahaleler gözle görülür hale gelmiştir. ${ }^{43} 1980$ 'lerin sonunda Türkiye’nin büyük bölümünde antenlerle, iletişim uydularından yapılan yabancı televizyon yayınları izlenmeye başlamıştır. Bu dönemde devlet bu yayınları ne yasaklamış ne de yasal bir düzenleme getirmiştir. 1990’ların başında Cumhurbaşkanı Turgut Özal, dönemin siyasileri kamu hizmeti yayıncılığının dışında özel yayıncılığın faaliyet göstermesi gerektiğini vurgulamışlar, TRT’yi tekelci konumuyla eleştirmişlerdir. Süleyman Sarılar bu dönemi şöyle yorumlamaktadır:

Yasalarla sağlanmış özerklikler vardı. Parlamenter sistemin tepesinde özellikle o dönemde ciddi bir denetim mekanizması, hükümetin üzerinde parlamentonun denetimi ve Sayıştay'ın denetimi vardı, yargının denetimi ve Cumhurbaşkanlığının denetimi söz konusuydu. Yani bugünkü gibi değildi. Özal da o dönemde istediği bir sürü şeyi yasallığa geçiremiyordu. İstediği adamı TRT’nin

40 Erol Mutlu, "Ne Olacak Bu Kamu Yayıncılığının Tarihi”, Medya Politikaları, der., Beybin Kejanlığlu, Sevilay Çelenk ve Gülseren Adaklı, Ankara: İmge Kitabevi, 2001, s.26.

41 Cem Pekman, “Avrupa Birliği’nde Kamu Hizmeti Yayıncılığının Finansmanı”, Marmara Avrupa Araştırmaları Dergisi, 12/1-2 (2004), s.336.

42 Engin Başçı, "Kamu Hizmeti Yayıncılığı Düzenlemelerinde Halkın Katılım ve Temsiliyet Biçimleri Üzerine Bir Değerlendirme (İngiltere-Almanya-Türkiye Örnekleri)", İstanbul Aydın Üniversitesi Dergisi, 10/4 (2018), s.61. 43 Kemal Aslan, İkna Ekranları, s.117-118. 
başına atayamıyordu. Yani 1960 Anayasası'nd hukuki güvenceler vardı. Onları değiştiremediği için daha kolay kontrol edebileceği, hem de özel sermayenin yatırım yapabileceği bir alanı açtı. Devletin tekelinden yayıncılığı çıkarıverdi. ${ }^{44}$

Tarihsel bağlamda TRT, 1968-1971 yılları arasında yasal olarak özerk ve tarafsız bir kurumdur. Ancak 1971 yılında yapılan bir düzenlemeyle özerkliği kaldırılmıştır. Diğer yandan TRT 1980'li yıllardan itibaren hem renkli televizyon yayınlarına geçmiş hem de yurt içi yurt dışına yayın yapan kanal sayısını artırmıştır. Ancak dünyadaki ekonomik değişim yayıncılıkta da etkisini gösterince, TRT siyasetin etkisi altında kalmakla, çok sesliliğe yeterince fırsat vermemekle eleştirilerek, reklama dayalı gelirle ticari televizyonların devreye girmesi gerekliliği liberal çevrelerce yoğun olarak dile getirilmiştir. Nitekim 1989 yılında kurulan ve dönemin Başbakanı Turgut Özal'ın oğlu Ahmet Özal'ın da ortağı olduğu Magic Box isimli şirkete ait "Star 1" televizyonu yasal düzenleme olmaksızın 1990 yılından itibaren televizyon yayıncıl1ğına başlamıştır. ${ }^{45}$ Kurulumu ve yayıncılığı yürürlükteki yasa ve mevzuata aykırı özel televizyon yayıncılığı, 1993 yılında yeni bir yasal düzenlemeyi beraberinde getirmiş ve özel televizyon ya da radyoların kurulması, serbest bırakılmıştır. ${ }^{46}$ Diğer yandan 2018 yılında Cumhurbaşkanlığı kararnameleri ile TRT’yi düzenleyen yeni hükümler yürürlüğe girmiştir. Buna göre; TRT, Türkiye Büyük Millet Meclisi (TBMM) denetiminden alınarak Cumhurbaşkanlığı İletişim Başkanlığı’na bağlanmış ve yönetim kurulunun yetkileri sınırlandırılmıştır. ${ }^{47}$

Tablo 5. Türkiye’de Kamu Hizmeti Yayıncılı̆̆ının Hukuksal Bağlamda Kronolojisi ${ }^{48}$

\begin{tabular}{|l|l|}
\hline 1927-1936 & $\begin{array}{l}\text { Tek partili dönemde, özel girişim (devlet destekli) kamu hizmeti } \\
\text { yayıncılığı. TTAŞ isimli şirket radyo yayınlarına başladı. }\end{array}$ \\
\hline $1936-1950$ & $\begin{array}{l}\text { Tek partili dönemde siyasetin güdümünde kamu yayıncılığı yapıldı. } \\
\text { Önce PTT’ye sonra Matbuat Umum Müdürlüğ̈̈’ne bağlandı. }\end{array}$ \\
\hline $1950-1960$ & $\begin{array}{l}\text { Çok partili dönem olsa da siyasetin/iktidarın güdümünde kamu } \\
\text { hizmeti yayıncılığı yapıldı. }\end{array}$ \\
\hline 1961 Anayasası & Darbenin ardından 121. maddeye “özerklik” ilkesi eklendi. \\
\hline $1964-1971$ & $\begin{array}{l}\text { 359 sayılı “TRT Yasası” ile 1964’te TRT kuruldu. Bu dönem gerçek } \\
\text { kamu hizmeti yayıncıllğı olarak kabul edilir. Yönetim kurulu } \\
\text { toplumun değişik kesimlerinden oluşan çoklu bir yapıya sahiptir } \\
\text { ayrıcı danışma kurulu da vardır. }\end{array}$ \\
\hline
\end{tabular}

44 Süleyman Sarılar ile mülakat, 21.05.2020.

45 Vedat Demir, Türkiye’de Medya Siyaset İlişkisi, İstanbul: Beta Basım, 2007, s.236.

46 İbrahim Uslu, “Televizyon Yayıncılığında Kamu Hizmeti Yayıncılı̆̆ı”, Uzmanlık Tezi, Radyo ve Televizyon Üst Kurulu, 2011, s.125.

47 “The Future of Turkish Public Broadcaster TRT and Its Emplooyees in Peril”, Uni Global Union, 28.08.2018, https://www.uniglobalunion.org/es/node/39475.

48 Türkiye'de kamu yayıncılığının Anayasa düzenlemelerine göre geçmişten bugüne tarihsel dönüşümü genel hatlarıyla aktarılmıştır. Bilgilerin derlendiği kaynaklar için bkz. Mustafa Şenay Canoruç, "Anayasal Kurum Olan TRT’nin ‘Özerkliğì”, Elektronik Sosyal Bilimler Dergisi, 8/27 (2009); Başçı, “Kamu Hizmeti”. 


\begin{tabular}{|c|c|}
\hline 1971-1980 & $\begin{array}{l}\text { Muhtıranın ardından } 1972 \text { Anayasası ile “özerklik” ilkesi kaldırıldı. } \\
\text { “Tarafsız kamu tüzel kişiliği” olarak tanımlandı. İktidarın } \\
\text { güdümünde kamu hizmeti yayıncılığı tekrar başladı. Protokol } \\
\text { haberciliği ön plana çıktı. İdari özerklik iktidara bağlandı, yayıncı } \\
\text { özerkliği kaldırıldı. Yönetim kurulu üyelerinin kontrolü siyasal } \\
\text { iktidarın elindedir. Genel Danışma Kurulu kurulmuştur. }\end{array}$ \\
\hline $\begin{array}{l}1982 \text { Anayasası ve } \\
\text { sonrası }\end{array}$ & $\begin{array}{l}\text { Darbenin ardından } 1983 \text { ’te } 2954 \text { sayılı TRT Kanunu’nda “Kamu tüzel } \\
\text { kişiliği devam etsin, siyasetin güdümünden çıksın” dendi. } \\
\text { Yasanın 19. Maddesiyle; siyasi partilere ayrılan zaman dilimlerinde } \\
\text { halka seslenebilme imkânı tanındı. Siyasetin devam eden güdümü ile } \\
\text { kamu hizmeti yayıncılığının yapılması söz konusu olmadı. TRT'de } \\
\text { dış yapımlar arttı. Mali sıkıntılar yaşandı. Yayıncı özerkliği kayboldu. } \\
\text { Genel Danışma Kurulu kaldıııldı, geçici danışma kurulları kuruldu. }\end{array}$ \\
\hline 1991-1993 & Özel yayıncılık hukuka aykırı olarak başladı. \\
\hline $\begin{array}{l}1993 \text { Anayasa } \\
\text { değişikliği }\end{array}$ & $\begin{array}{l}1982 \text { Anayasası’nın 133. Maddesi değişti: } \\
\text { TRT tekeli kalktı, özel televizyonlara hukuksal statü verildi. } \\
\text { TRT, “özerk” kimliğini } 32 \text { yıl sonra tekrar kazandı. }\end{array}$ \\
\hline $\begin{array}{l}2018 \\
\text { Cumhurbaşkanlığı } \\
\text { Kararnamesi }\end{array}$ & $\begin{array}{l}\text { Cumhurbaşkanlığı hükümet sistemine geçişle danışma kurulları } \\
\text { tümüyle kaldırıldı. } \\
\text { 2018’ de TRT Cumhurbaşkanlığı İletişim Başkanlığı’na bağlandı. } \\
\text { Kararnameye göre yönetim kurulunun yetkileri sınırlandırıldı. }\end{array}$ \\
\hline
\end{tabular}

\section{Britanya Kamu Yayıncılığı}

Avrupa’nın kamu yayıncılığı konusunda model aldığı ülke İngiltere’nin kamu hizmeti yayıncısı olan Britanya Yayın Kuruluşu (British Broadcasting Corporation-BBC) eliyle yürütülmektedir. 1922 yılında altı radyo üreticisinin kurduğu bir yayın kuruluşu olan BBC, alt sınıfların kütüphaneler ya da müzeler gibi kamu kurumları arac1lı̆̆ıla kültürel olarak geliştirilmesi şeklinde özetlenen Viktoryen ideallerin, kamu hizmet yayıncılığı alanındaki devamıdır. BBC, 1923 yılında radyo yayıncılığının özel mülkiyete bırakılamayacak kadar ciddi bir iş olduğu kararı doğrultusunda 1927 y1lından itibaren kamu yayıncılığına geçmiştir. Ancak her ne kadar yasal bakımdan BBC bir kamu kurumu olarak tanımlanmış olsa da yayın politikalarının belirlenmesinde iktidar ile arasına koyacağı mesafe güvence altına alınmıştır. ${ }^{49}$ Dolayısıyla BBC yayıncılığı; uzlaşmacı, tarafsız, politika ve politikacılara mesafeli olabilmiştir.

Ancak 1954 yılında BBC’nin devlet tekeli anlayışının yarattığ düşünülen sıkıntıları bertaraf etmek için Independent Television (ITV) kurulmuştur. Böylece kamudaki yayıncılık tekeli kaldırılmış, 1955'te ilk özel televizyon girişimi ortaya çıkmıştır. ITV 15 bölgesel televizyonun oluşturduğu bir kuruluştur. ITV 'nin Amerikan tarzı özel yayıncılık anlayışı başlangıçta BBC’nin seyirci kaybetmesine neden olsa da zaman içinde İngiliz siyasal kültür anlayışı ITV’yi de BBC’nin kamu hizmeti yayıncısı anlayışına çekmiş, bunu yasalar ile garanti altına almıştır. Bu durumu şöyle özetlemek mümkündür: ticari bir televizyon da olsa belli bir bedelle, kullanım iznini aldığı ya

49 “Medya Konuşmaları: Kamu Hizmeti Yayıncılığı”, Açık Radyo, 13.06.2006, https://acikradyo.com.tr/arsivicerigi/medya-konusmalari-xiii-kamu-hizmeti-yayinciligi. 
yın frekansına karşılık belli hak ve yükümlülüklere tabiidir. BBC, yıllar içinde yayın politikasında değişimler yaşasa da yayıncı kurumlar arasında saygın bir üst kurum olarak kalmaya devam etmiştir.1980’lerle birlikte İngiltere Başbakanı Thatcher döneminde muhafazakâr partinin özelleștirme politikalarına, yayınlarından reklam alınsın mı alınmasın mı tartışmalarına muhatap olmuştur. Sonuçta İngiliz siyasal kültür anlayışının etkisiyle kar odaklı televizyon anlayışından uzak kalmayı başarabilmiştir. ${ }^{50} \mathrm{BBC}$ yayın ilkelerine göre haberde karşıt görüşlere yer verilmeli, haberin tüm unsurları yer almalıdır. İkinci Dünya Savaşı’nda, Alman yayıncılığının haberleri nesnel sunmadığına inanan Alman halkının doğru haber alabilmek için BBC'yi takip ettiği bilinmektedir. 2016'daki bir araştırmada izleyenlerin yüzde 89'u BBC'nin çok güvenilir olduğunu söylemiştir. BBC geçmişte bağımsızlığına gölge düşürecek siyasi ve ticari bir ihlal yaşamamıştır. ${ }^{51}$ Halk kamu yayıncılığına katılımını, danışma kurullarındaki geniş temsilci yelpazesi ile sağlar.

\section{Amerika Birleşik Devletleri’nde Kamu Yayıncılığı}

Amerika'da ticari yayıncılık rağbet gördüğünden, halkın bilgilendirilmesi, eğitilmesi geri planda kalmış, izleyici müşteri gibi değerlendirilmiştir. ${ }^{52}$ Kamu hizmeti yayınc1ları Avrupa’daki gibi devlet televizyonları değildir. Böyle bir ortamda kamu hizmeti yayıncılığı kavramı da ticari yayıncılıktan beklenir. Federal Haberleşme Komisyonu (FCC-Federal Communication Commission) yayın talebinde bulunanlara lisans vermekle mükellef bir kurumdur. Ancak FCC yayın lisansı vermek için kuruluşların sadece yeterliliklerine bakmaz, aynı zamanda kamu yararını önde tutup tutmadıklarını da denetler, öneri verir ama yaptırım yetkisi yoktur. ${ }^{53}$

\section{Almanya'da Kamu Yayıncılı̆̆ı}

Avrupa'da dikkat çeken bir ilke ticari yayıncılık devletten bağımsız, düzenleyici kurum da hükümetten bağımsız olmak zorundadır. Bu durum, Almanya ve İngiltere'de yasalarla teminat altına alınmakta, gelişmiş diğer Avrupa ülkelerinde ise o ülkelerde yerleşmiş siyasi kültürün bağımsız yayıncılık açısından teminat olduğu görülmektedir. ${ }^{54} 2014$ yılında siyasi partilerin ZDF üzerindeki endişeleri üzerine harekete geçen Anayasa Mahkemesi’nin, kamu hizmet yayıncılığının bağımsızlığını güçlendirme girişimi buna bir örnektir. Karara göre ZDF' nin iki denetim organının her birindeki üye sayısı toplam sayının üçte birini geçemeyecekti. ${ }^{55}$ Almanya'da eşit temsilden oluşan yayın konseyleriyle federalist bir yapı vardır. İki kamu hizmeti yayıncısının ARD ve ZDF'nin hükümetten bağımsız idari konseyleri vardır. Bu konseyler; kilise, gazete, kültür örgütleri, üniversiteler vs. gibi kuruluşların seçtiği üyelerden ve toplam

50 Uslu, “Televizyon Yayıncılığında”, s.106-107.

51Radu Raluca, “Europe's Public Service Media: Between Responsibility and Accountability”, EJO: European Journalism Observatory, 21.03.2018, https://en.ejo.ch/media-economics/accountable-and-or-responsiblepublic-service-media-in-europe.

52Uslu, "Televizyon Yayıncılı̆̆ında”, s.101.

53 Kayıhan İçel, Kitle Haberleşme Hukuku, İstanbul: Beta Yayınları, 2001, s.101-102.

54 Uslu, “Televizyon Yayıncılığında”, s.109-112.

55 Raluca, "Europe's Public". 
üyelerin üçte birinden fazla olamayan yasama organlarının seçtiği siyasi parti adaylarından oluşmaktadır. ${ }^{56}$

\section{Türkiye'deki Kamu Yayıncılığı Ůzerine Bulgular ve Değerlendirmeler}

Kamu Yayıncılığı tüm dünyada farklı başlıklar altında 1980’li yıllardan bu yana tartışmalara neden olmaktadır. Bunlardan biri finansman açıklarıdır. Türkiye’de de TRT’nin harcamaları ve vergilerden aldığı pay kamuoyunda sıkça gündeme gelmektedir. 3093 sayılı Türkiye Radyo Televizyon Kurumu Gelirleri Kanunu'na göre TRT'nin gelirleri: elektrik faturalarından alınan pay, radyo-televizyon-video ve birleşik cihazlardan tahsil edilen gelirler, ilan ve reklam gelirleri, konser ve temsillere ödenen giriş ücretleri, film-plak-dergi-kitap gibi yayınların satışından elde edilen gelirler ve genel bütçeden yapılan katkılardan oluşmaktadır. ${ }^{57} 2019$ yılında TRT gelir kalemlerinde yapılan bir değişiklikle televizyon-radyo-birleşik cihazlardan alınan bandrol payları artırılmış, buna göre cep telefonlarından $\% 6$, bilgisayar ve tabletlerden \%2 pay alınmaya başlamıştır. ${ }^{58}$ TRT’nin günümüzde en büyük gelir kalemi bandrol ücretleri ve elektrik faturalarından alınan paylardır. Bunları sırasıyla reklam gelirleri ve program satışları takip eder. Engin Başçı'ya göre “TRT hiç reklam almasa da kendini finanse edebilir. Ancak siyasiler kamu hizmeti televizyonlar üzerinde kontrol ve baskıyı artırmak için ruhsat gelirlerini düşürmeyi bir koz olarak kullanabilmektedirler." 59

Avrupa Yayın Birliğinin (EBU) verilerine göre yabancı kamu yayıncılarının (bütçelerine göre orantılandığında) en önemli geliri halktan alınan lisans (halkın kamu yayıncılarını izleme karşılı̆̆ında ödediği ücret) ücretleridir.

Tablo 6. Avrupa'daki Kamu Hizmeti Yayıncı Kuruluşlarının Finansal Kaynaklarının Yüzdelik Oranları (Her kamu kuruluşunun kendi toplam bütçesi üzerinden oranlar hesaplanmıştır) (2005)

\begin{tabular}{|l|l|l|l|l|l|}
\hline Ülke & $\begin{array}{l}\text { Kamu Yayıncısı } \\
\text { Kuruluş }\end{array}$ & $\begin{array}{l}\text { Kamu } \\
\text { fonları }\end{array}$ & $\begin{array}{l}\text { Lisans } \\
\text { ücretleri }\end{array}$ & $\begin{array}{l}\text { Reklam } \\
\text { gelirleri }\end{array}$ & $\begin{array}{l}\text { Diğer } \\
\text { kaynaklar }\end{array}$ \\
\hline Almanya & ARD & $\% 0,6$ & $\% 82$ & $\% 2$ & $\% 14$ \\
\hline İngiltere & BBC & $\% 5$ & $\% 73$ & - & $\% 21$ \\
\hline Fransa & Tele France & $\% 0,3$ & $\% 65$ & $\% 28$ & $\% 5$ \\
\hline İtalya & RAI & - & $\% 52$ & $\% 39$ & $\% 8$ \\
\hline
\end{tabular}

(Avrupa Yayın Birliği verileri üzerinden ${ }^{60}$ finansal kaynak oranları hesaplanmıştır).

Türkiye’de ise elektrik faturaları TRT’nin en önemli gelir kalemi iken, artırılan bandrol ücretleri günümüzde birinci sırayı almıştır. Başçı, halkın vergilerinin TRT’nin

56 Uslu, “Televizyon Yayıncılığında”, s.114.

57 “Türkiye Radyo Televizyon Kurumu Gelirler Kanunu”, TRT, https://www.trt.net.tr/bandrol/mevzuat/. (erişim 01.09.2020).

58 Başak Kaya, “TRT 92 Milyon TL Zarar Etti”, Sözcü, 14.12.2019, https://www.sozcu.com.tr/2019/ekonomi/ donmez-madencileri-zeytin-ureticisi-yaptik-5508990/.

59 Engin Başçı ile mülakat, 21.07.2020.

60 Kenan Duman, "Deregülasyon Sonrası Kamu Hizmeti Yayıncılığı: RAI ve TRT Üzerine Karşılaştırmalı Analiz”, Ulakbilge, 6/20 (2018). 
bağımsızlığının garantisi olduğunu belirtmektedir: "Mali anlamda bağımsız olmalı, sabit gelir kalemleri olmalı. TRT bütün halkı temsil eden parlamentoda belirlenen bir yapı. Sorumluluk iktidara değil halka karşı olmalıdır çünkü halkın vergileriyle TRT varlığını sürdürüyor.”'1

Ragıp Duran, kamu yayıncılığı alanında finansman sıkıntısının tüm dünyada yaşandığını belirtmektedir:

BBC harçla çalışıyor. İç yayınlar için reklam almıyor. Ama uluslararası yayın yapan BBC Word reklam alıyor. Yarın belki BBC yerel de reklam almaya başlayabilir. Finansmanını artırmak için birkaç yıldır belediyelere, sivil toplum kuruluşlarına belli kurallara uymak şartıyla yayın saati satıyor. İngiltere'de hükümet bütün kamu bütçelerinde kısıtlamaya gidiyor; sağlık, iletişim sektörleri de bunların arasında. Toplanan bütçe gelişen teknoloji ve ihtiyaçlara yetmiyor. Ben çalıştığım dönemde BBC'de yabancı dilde yayıncılık yapan kanal 39 civarıydı şimdi 26'lara düştü. Krizden çıkışın yolu olarak paralı aboneliğin de fayda etmeyeceği anlaşıldı, çünkü sürekli fiyatlar artıyor. ${ }^{62}$

Duran, neo-liberal yayın kuruluşlarının mülkiyet yapılarında büyük sermayedarlara ihtiyaç duyduğunu, ancak her şeye rağmen editoryal bağımsızlığın korunabileceğini belirtmektedir:

Liberation, Le Monde gibi gazeteler kooperatif gibiydi; mülkiyetinin \%70’i çalışanlarındı. Onlar da neo-liberalizm yüzünden büyük hisselerini telefon şirketlerine, holdinglere satmak zorunda kaldılar. Ancak yine de editoryal bağımsızlığa ülkenin siyasi geleneğinden dolayı uymak zorundalar. Washington Post'un sahibi Amazon'un da sahibi. Ama buna rağmen pandemi döneminde kovitli Amazon çalışanlarını kamuoyuna duyurdular. Demokratik kültürü olan ülkelerde kamu yararı hala gözetiliyor. ${ }^{63}$

Mali özerklik dışında kamu yayıncılığının bir başka tartışma konusu da idari özerkliktir. Engin Başçı, 2018 yılında TRT ile ilgili çıkarılan kararnamenin kurumun bağımsızlığını gölgelediği belirtmektedir:

1961 Anayasası'nda yedi yönetim kurulu üyesinden sadece ikisini hükümet seçiyordu, geri kalanlar sendika ve üniversite temsilcileriydi; onlar genel müdürü seçiyordu. 15 Temmuz'dan sonra TRT'ye iki kararname getirdiler, yapısını değiştirdiler. Genel Müdürü yönetim kurulu nezdinde güçlendirdiler. Şimdi bütün üyeleri hükümet atıyor. Aslında genel müdür istifa etmedikçe onu kimse görevinden alamaz ancak o makamda oturan da kendi seçene kuluymuş gibi davranıyor. BBC'deki siyasi gelenekle genel müdür bütün iktidar partilerine eşit mesafede. BBC Falkland Adaları olayında İngiliz Hükümeti’ni eleştirdi, bizde bunu asla yapamazsinız. ${ }^{64}$

61 Engin Başçı ile mülakat, 21.07.2020.

62 N. Beril Ekşioğlu Sarılar, Ragıp Duran ile mülakat, 27.06.2020.

63 Ragıp Duran ile mülakat, 27.06.2020.

64 Engin Başçı ile mülakat, 21.07.2020. 
Süleyman Sarılar da TRT kurumunu bu minvalde değerlendirmektedir: "Mali özerklik, idari özerklik, editoryal bağımsızlık hiçbiri yok. Kağı üzerinde TRT özerk gibi gözüküyor ama biliyoruz ki genel müdürü dahil hepsini iktidar atıyor.”65

TRT’nin yıllar içinde değişen siyasal bağlamdaki yayıncılık eğilimi izleyici profilini de farklılaştırmıştır; her tercihten, her inanıştan oluşan geniş halk topluluğunun yerini ağırlıklı olarak tek tip izleyici profili almıştır.

Tablo 8. KONDA’nın Televizyon İzleyicilerinin Hayat Tarzlarına Dönük Araştırması: TRT'nin Değişen İzleyici Profiliti

\begin{tabular}{|l|l|l|}
\hline 2012'den 2018'e & Modern izleyici & \%17'den \%10'a geriledi \\
\hline 2012'den 2018'e & Dindar, muhafazakâr izleyici & \%30'dan \%37'e çıtı \\
\hline 2018 yllı & Geleneksel muhafazakâr izleyici & $\% 53$ \\
\hline
\end{tabular}

Kamuoyunun siyasal, kültürel eğilimlerini araştıran Konda’ya göre 2012-2018 yılları arasındaki altı yıllık dönemdeki izleyici profilinin \%90’ının muhafazakâr kesimden olması, TRT’nin mevcut iktidardaki partinin ideolojisi doğrultusunda yayın yaptığ1nın göstergesi olarak değerlendirilebilir. Gazeteci Ragıp Duran’a göre, kamu hizmet yayıncılığı giderek daha fazla siyasal iktidarların ideolojik propaganda aletine dönüşmektedir:

Üçüncü dünya ülkelerinde kamu yayıncılığı devlet yayıncılığına dönüştü. Devletin hazinesinden beslenen gazetecilere resmi memurluk yaptırıyorlar. Gramsci 'nin bir dönem siyaset için söylediği temel tezlerinden biri bugün medya için çok geçerli; kim egemense siyasette o topluma ideolojik anlamda da egemendir. Türkiye'de özellikle özel sektör yayıncılığının da devlet/hükümet yayıncılığı haline gelmesi, gazeteci tipolojisini de aynılaştırdı. Bugün TRT'de çalışanla A Haber'de çalışan aynı gazeteci gibi, çok seslilik yok oldu, tekelleşme oluştu. ${ }^{67}$

Kamu yayıncısının bir ülkedeki izlenme oranı yapılan yayınların siyasal/kültürel bağlamda tüm kesimlere hitap edip etmediğinin göstergesi olarak kabul edilebilir.

Tablo 7. Ülkelere Göre Kamu Yayıncılarının Pazar Payları ${ }^{68}$

\begin{tabular}{|l|l|l|}
\hline Ülke & Kamu yayıncısı kuruluş & Pazardaki payı \\
\hline Almanya & ARD ve ZDF & $\% 44,5$ \\
\hline İngiltere & BBC & $\% 38,5$ \\
\hline Türkiye & TRT & $\% 8,3$ \\
\hline İtalya & RAI & $\% 46,4$ \\
\hline Fransa & FRANCE 2,3 & $\% 37,2$ \\
\hline
\end{tabular}

65 Süleyman Sarılar ile mülakat, 21.05.2020.

66 KONDA, "KONDA Medya Raporu: Televizyonla Değişen Algılar, Sosyal Medyanın Yükselişi ve 10 Yıllık Medya Serüvenimiz 2008-2018”, Kasım 2019, https://konda.com.tr/wp-content/uploads/2019/12/KONDA_ MedyaRaporu_HT2018.pdf/. (erişim 01.09.2020).

67 Ragip Duran ile mülakat, 27.06.2020.

68 Werner Rumphorst, “The Position of Public Broadcasting in Europe: An Essential Cohesion”, Geneve: EBU (The European Broadcasting Union), 2004, s.7-8. 
Avrupa Yayın Birliği’nin (EBU) 2004'te yayınladığı verilere göre, TRT ulusal platformda diğer ülkelerin kamu yayıncılarına göre düşük bir izleyene sahiptir. Süleyman Sarılar, halkın tek sesli yayıncılığı tercih etmediğini bunu da izlenme oranlarıyla ortaya koyduğunu belirtmektedir: "Türkiye gibi demokratik olgunluğa ulaşmayan ülkelerde, kamu yayıncılığı tümüyle iktidarın bir baskı aygıtı ve propaganda aygıtı haline dönüşüyor. Dolayısıyla izlenme payları düşüyor." ${ }^{99}$ Ragıp Duran'a göre kurum yapılarındaki değişim, gazetecinin haber dilini de değiştirmiştir:

1980 sonrası Thatcher orta sınıfı kendine çekmek için, hızlı, görsel, yüzeysel bir taktik uyguladı. Eskiden gazetecilik olguya dayanırdı, oysa şimdi görselliğe, sanallığa ve yüzeyselliğe dayanıyor. Gazetecilik hakikatten sıyrıldı işte bu yüzden gerçek ötesi (post-truth) deniyor. Haberin dili “-di'li” geçmiş zamand,, şimdi “-miş'li” geçmiş zaman. İktidarı savunmak, özel çıkarı savunmak sayılır oysa gazetecinin görevi kamu çıkarını savunmaktır. ${ }^{70}$

Engin Başçı toplumun geniş kesimlerinden oluşan danışma kurullarının kaldırılmasının özerkliğin zedelenmesinde kritik bir dönemeç olduğunu vurgulamaktadır:

Halk adına halkın geniş kesimlerinden oluşan danışma kurulları, halkın kurumun yönetime katılım biçimiydi. Danışma kurullarında halk adına halkı temsil eden sivil toplum örgütleri, meslek örgütleri, üniversiteler, eğitim kurumları temsilcileri vardı. Bu kuruldaki temsilciler TRT’nin program politikalarına öneriler getiriyorlardı. Bu kurul 1983'e kadar fiilen devam etti. Bu danışma kurullarının olmaması TRT’nin ticari kaygılarla hareket ettiğini, halkın televizyonu kavramından uzaklaştığının gösterir. ${ }^{71}$

Kamu yayıncılığının gerekliliği konusunda üç gazeteci farklı görüşlere sahip olsa da kamu adına hizmet eden bir medya için gelişmiş bir demokrasinin varlığına duyulan ihtiyaç ortak noktaları olarak öne çıkmaktadır. Sözgelimi Süleyman Sarılar’ a göre:

Eğer sistem yeterince demokratikse ve demokrasi kurallarıyla işliyorsa bence kamu yayıncılığına ihtiyaç yok. Çünkü kamu yayıncıları bir süre sonra iktidarların, ister istemez denetlediği bütçe olarak bağlı oldukları için, iktidarları en azından gücendirecek yayınlardan kaçınan bir yapıya dönüşüyor. ${ }^{72}$

Bu minvalde Engin Başçı şu görüşü dile getirmiştir:

Kamu yayıncılığının gerekli olduğunu düşünüyorum. Ama özerklik çok önemli, neden bandrol ücreti kesiyorlar, halkın vergileriyle çalışan bir kurum olarak halka sorumluluk duysun diye. TRT reyting kaygısıyla hareket etmemeli. Reklam alma savaşı reyting fetişizminin kurbanı oluyor yayıncılar. Hepsi tek tip yayın yapıyor: evlilik, yemek vs. programları gibi. Çok seslilik adı altında aslında kalitesiz programlarla tek sese döndü televizyonlar. ${ }^{73}$

69 Süleyman Sarılar ile Mülakat, 21.05.2020.

70 Ragıp Duran ile mülakat, 27.06.2020.

71 Engin Başçı ile mülakat, 21.07.2020.

72 Süleyman Sarılar ile mülakat, 21.05.2020.

73 Engin Başçı ile mülakat, 21.07.2020. 
Ragıp Duran ise şu şekilde durumu özetlemektedir:

Neo-liberal politikaların bir korsan gibi medya dünyasını çalmasıyla, özellikle kamu yayıncılığı gazetecilik açısından bir kurtuluş yolu olarak görülmeye başlamıştı. Ama bugün bu düşünceler hüsrana uğradı. Ancak tüm dünyada neo-liberal sistemin yıkıntıları anlaşıldığı zaman, dünya daha iyiye gidebilir. Bence tek başına gazeteciliğin bir çıkışı yok. Çıkış yolu dengeli bir gelir dağılımı, ideolojik/siyasal daha iyi bir toplumsal yapı. Demokrasinin olmadığı bir ortamda ne özel sektör ne de kamu yayıncısı gerçek kamu hizmeti yayıncılı̆̆ı yapamaz. ${ }^{74}$

\section{Sonuç}

1980’lerden sonra yaygınlaşan neo-liberal politikalarla ve devletin piyasadan elini çekmesiyle pazar kendi dinamiklerine bırakılmış, medyaya girmeden önce başka sektörlerde faaliyet gösteren şirketler medyayı ele geçirmişler ve kendi amaçları doğrultusunda kullanmışlardır. Türk medyası bu dönemden itibaren medya- sermaye -devlet ilişkisi ekseninde şekillenmiştir. Holdingleşen medyada ticari çıkarlar medya patronunu iktidara, iktidar da kamuoyu nezdinde politikalarını meşrulaştırmak arzusuyla medya sermayesine yakınlaşmıştır. Menfaatler çerçevesinde iki tarafın birbirine karışmış bu ilişkisinde, iktidar medyayı kamuoyunu manipüle edecek bir araç olarak kullanmıştır. Dolayısıyla özel/tecimsel yayıncılık çok seslilik, özgürlük beklentilerini boşa çıkarmış; kamuya hizmet eden yayıncılık anlayışının karşılığını verememiştir.

İktidarın yasal ve ticari baskılarla medyayı kontrol altında tutma girişimi Türkiyede basın özgürlüğü sorununu da doğurmaktadır. Nitekim Sınır Tanımayan Gazeteciler Örgütü verilerine göre (Reporter Sans-Frontieres) 2018'de Türkiye basın özgürlüğü endeksinde 180 ülke arasında 157. sıradadır. Oysa demokratik bir ortamda her birey enformasyona eşit ulaşabilmeli ve çoğulcu bir yayın politikası içinde kendini ifade edebilme hakkına sahip olabilmelidir. Özel sektörün hâkim olduğu medyanın iktidarla olan ekonomik bağı/bağımlılığı basını tek sesliliğe, bir başka deyişle tekelleşmeye sürüklemiştir. Türkiye gibi dünya da bu çıkmazda kamuya hizmet edebilecek yayıncılık formüllerinin arayışına girmiştir: bunlardan biri de kamu yayıncılığıdır.

Bu çalışmada, tek sesli hale gelen medya sektöründeki mevcut durum özetlenmiş, kamu hizmeti yayıncısı TRT’nin analizi yapılmıştır. TRT’nin toplumun çoğulcu yapısını yansıtabilecek özerkliğe, şeffaflığa ve bağımsızlığa nasıl kavuşabileceği tartışılmıştır. Kamu yayıncısı kimliğiyle TRT’nin kamuoyuna gerçek bir hizmet verebilmesi için idari ve mali özerkliğe, editoryal bağımsızlığa sahip olması gerekmektedir. TRT’nin finansmanı halkın vergileriyle sağlansa da kurum geniş kitleler tarafından siyasi iktidarların ideolojik propaganda aleti olarak görülmektedir. Batı demokrasilerine bakıldığında, halkın kamu yayıncısının yayın politikalarına bizzat yönetimde yer alarak ya da danışma kurulunda tavsiyelerde bulunarak katılabildiği görülmekte-

74 Ragıp Duran ile mülakat, 27.06.2020. 
dir. Örneğin İngiltere'de halkın danışma kurulları vasıtasıyla kamu yayıncısının ürettiği içeriğe tavsiye anlamında katkısı bulunmaktadır. Aynı şekilde Almanyada halk yönetim kurullarında doğrudan yer alarak yayın politikalarının belirlenmesinde rol oynamaktadır. Türkiyede ise halkın kamu yayıncılığı politikalarına katılımı danışma kurullarının kaldırılmasıyla tamamıyla sona ermiştir. Oysa bağımsızlık, tarafsızlık ilkeleri açısından bu katılım çok değerlidir. Yayınları düzenleyen, denetleyen Radyo ve Televizyon Üst Kurulu (RTÜK) üyeleri de yine parlamentodaki siyasi parti üyelerinden seçilmekte, halkın doğrudan temsili burada da söz konusu olamamaktadır.

Kamu yayıncısının mali özerkliğinin yasalarla/düzenlemelerle koruma altına alınması; bütçesinin halktan alınmış katkı paylarıyla oluşması gerekmektedir. Halkın finanse ettiği bir kuruluş olsa da TRT İngiltere gibi reklamsız bir yayıncılık anlayışını değil, diğer Avrupa ülkelerine benzer şekilde kar odaklı, reklam pastasından pay almayı amaçlayan bir yayın çizgisini hedeflemiştir. Dolayısıyla bu durum yayın politikasına yansımakta, reyting baskısıyla hareket etmekte, tecimsel televizyonlarla reklam yarışına girmektedir. Sayıştay'in yayınladığı 2017 yılı TRT’nin gider kalemleri raporuna göre, kurumun gelirinin yüzde 56,6 ‘sı kurum dışı yapımlara aktarılmaktadır. Bu oranının yüksekliği muhalefetin de kurumun kaynaklarının iyi kullanılmadığ́1 yönünde eleştirilerine neden olmaktadır. TRT asli görevi olan, toplumu eğitecek, kültürel bağlamda geliştirecek içerik üretiminden uzaklaşabilmekte, prime time kanallarıyla rekabet edecek pahalı yapımlara yönelmektedir. Oysa TRT’nin kaliteli programlar üretmek konusunda, BBC’nin İngiltere'de özel sektörü domine etmesi gibi bir role bürünmesi gerekmektedir. Demokratik çoğulcu toplumun önerdiği gibi, halkın vergileriyle finanse edilen kamu yayıncısının izleyiciyi/okuyucuyu bir tüketici olarak değil vatandaş olarak görmesi şarttır. TRT ticari televizyonlarla yarışmak yerine, onların boş bıraktığı alanlara nüfuz edip halka kaliteli, eğitici programlar sunmayı amaç edinmelidir. Aslında ister tecimsel ister kamusal olsun kamu hizmeti yayıncısının halkın doğru, nesnel, çok sesli bir ortamdan beslenmesini sağlaması gerekir, bunun için yayıncılara yasal düzenlemelerle, kamuoyuna yarar sağlayacağı düşünülen programları prime time’ da yayınlama zorunluluğu gibi yaptırımlar getirilebilir.

Öte yandan genel anlamda baktığımızda sağlıklı bir medya ortamı için: güçlenen sermayenin demokratik toplumlarda sınırlandırılmasının kaçınılmaz olduğunun; kamu hizmeti yayıncılığının siyasal geleneklerle korunamadığı ortamlarda, kanunlarla koruma altına alınması gerekliliğinin de vurgulanması gerekir.

Görüşme yapılan gazeteciler, gelecekte özgür bir medyanın kamu yayıncılığından çok internet üzerinde yapılan, patronaj yapısının yer almadığı bağımsız gazetecilikle oluşabileceğini aktarmışlardır.

\section{Kaynakça}

Adaklı, Gülseren. Türkiye’de Medya Endüstrisi. Ankara: Ütopya Yayınevi, 2006.

Ahmad, Feroz. Demokrasi Sürecinde Türkiye (1945-1980). Çev., Ahmet Fethi. İstanbul: Hil Yayınları, 1994.

Aslan, Kemal. İkna Ekranları. İstanbul: Anahtar Kitaplar Yayınevi, 2014. 
Başçı, Engin. "Kamu Hizmeti Yayıncılı̆̆ı Düzenlemelerinde Halkın Katılım ve Temsiliyet Biçimleri Üzerine Bir Değerlendirme (İngiltere-Almanya-Türkiye Örnekleri)”. İstanbul Aydın Üniversitesi Dergisi. 10/4 (2018): 59-74.

Canoruç, Mustafa Şenay. “Anayasal Kurum Olan TRT’nin 'Özerkliği”. Elektronik Sosyal Bilimler Dergisi. 8/27 (2009): 16-45.

Çoban, Savaş. Hegemonya Aracı ve İdeolojik Aygıt Olarak Medya. İstanbul: Parşömen Yayıncilık, 2013.

Demir, Vedat. Türkiye’de Medya Siyaset İlişkisi. İstanbul: Beta Basım, 2007.

Duman, Kenan. "Deregülasyon Sonrası Kamu Hizmeti Yayıncılığı: RAI ve TRT Üzerine Karşılaştırmalı Analiz”. Ulakbilge. 6/20 (2018): 59-84.

Erdoğan, İrfan ve Korkmaz Alemdar. Öteki Kuram Kitle İletişim Kuram ve Araştırmalarının Tarihsel ve Eleştirel Bir Değerlendirmesi. Ankara: Pozitif Matbaacilık, 2010.

Golding, Peter ve Graham Murdock. "Kültür, İletişim ve Ekonomi Politik". Çev., Beybin Kejanlığlu. Medya, Kültür, Siyaset. Der., Süleyman İrvan. Ankara: Pharmakon Yayınevi, 2014: 49-75.

Güngör, Nazife. İletişim Kurumlar Yaklaşımlar. Ankara: Siyasal Kitabevi, 2013.

Herman, Edward S. ve Noam Chomsky. Rızanın Imalatı: Kitle Medyasının Ekonomi Politiği. Çev., Ender Abadoğlu. İstanbul: BGST Yayınları, 2006.

İçel, Kayıhan. Kitle Haberleşme Hukuku. İstanbul: Beta Yayınları, 2001.

İrvan, Süleyman. “Demokratik Sistemde Medyanın Rolü”. Birikim. 68-69 (1995): 7683.

Kaya, Başak. “TRT 92 Milyon TL Zarar Etti”. Sözcü. 14.12.2019. https://www.sozcu. com.tr/2019/ekonomi/donmez-madencileri-zeytin-ureticisi-yaptik-5508990/.

KONDA. "KONDA Medya Raporu: Televizyonla Değişen Algılar, Sosyal Medyanın Yükselişi ve 10 Yıllık Medya Serüvenimiz 2008-2018”. 2019. https://konda.com. tr/wp-content/uploads/2019/12/KONDA_MedyaRaporu_HT2018.pdf/. (erişim 01.09.2020).

Marx, Karl ve Friedrich Engels. Alman İdeolojisi. Çev., Sevim Belli. Ankara: Sol Yayınları, 2004.

Media Ownership Monitor Türkiye. “Medya ve Siyaset”. Erişim 17 Ağustos, 2020. https://turkey.mom-rsf.org/tr/.

"Medya Konuşmaları: Kamu Hizmeti Yayıncılığı”. Açık Radyo. 13.06.2006. https:// acikradyo.com.tr/arsiv-icerigi/medya-konusmalari-xiii-kamu-hizmetiyayinciligi.

Muratoğlu, Bahar. “Bir Demokrasi Masalı: Özgür Birey, Bağımsız Medya”. Pivolka. 20/6 (2011): 9-11.

Mutlu, Erol. "Ne Olacak Bu Kamu Yayıncılığının Tarihi”. Medya Politikaları. Der., Beybin Kejanlığlu, Sevilay Çelenk ve Gülseren Adaklı. Ankara: İmge Kitabevi, 2001.

Özsever, Atilla. Tekelci Medyada Örgütsüz Gazeteci. İstanbul: İmge Kitabevi, 2004. 
Pekman, Cem. "Avrupa Birliğinde Kamu Hizmeti Yayıncılı̆̆ının Finansmanı". Marmara Avrupa Araștırmaları Dergisi. 12/1-2 (2004): 335-349.

Raluca, Radu. "Europe's Public Service Media: Between Responsibility and Accountability". EJO: European Journalism Observatory. 21 Mart 2018. https:// en.ejo.ch/media-economics/accountable-and-or-responsible-public-servicemedia-in-europe (erişim 1 Eylül, 2020).

Rumphorst, Werner. "The Position of Public Broadcasting in Europe: An Essential Territory for Cohesion". Geneve: EBU (The European Broadcasting Union), 2004.

Sadakaoğlu, Mustafa C. "Yeni Türk Sinemasinda Modern Melodram Geleneksel Söylem”. Motif Akademi Halkbilimi Dergisi. 12/28 (2019): 1183-1200.

Schram, Ashley, Arne Rückert, Ronald Labonte ve Benjamin Miller. "Media and Neoliberal Hegemony: Canadian Newspaper Coverage of the Trans-Pacific Partnership Agreement". Studies in Political Economy. 16/97 (2016): 159-174.

Selen,Tavsife. "Çok Gazete Çok Bilgi Değilmiş Meğer!". Bianet, 18.01.2003. http:// bianet.org/bianet/print/16059-cok-gazete-cok-bilgi-degilmis-meger.

"The Future of Turkish Public Broadcaster TRT and Its Emplooyees in Peril". Uni Global Union, 28.08.2018. https://www.uniglobalunion.org/es/node/39475.

“Türkiye Radyo Televizyon Kurumu Gelirler Kanunu”. TRT. https://www.trt.net.tr/ bandrol/mevzuat/.

“Türkiyede Gazete ve Dergi Tirajları: 10 Yılda Yarı Yarıya Azaldı". Journo, 20.07.2020. https://journo.com.tr/gazete-dergi-tiraj.

Uslu, İbrahim. "Televizyon Yayıncıllğında Kamu Hizmeti Yayıncılığı”. Uzmanlık Tezi. Radyo ve Televizyon Üst Kurulu, 2011.

Yaylagül, Levent. "Eleștirel Ekonomi Politik Perspektiften Devlet ve Medya İlişkisi". Maltepe Üniversitesi İletişim Fakültesi Dergisi. 5/2 (2019): 134-152. 
İNSAN\&İNSAN, Y11/Year 7, Say1/Issue 26, Güz/Fall 2020, 41-64

DOI: https://doi.org/10.29224/insanveinsan.791980

\title{
The Impact of Neo-liberal Policies on Media and Public Service Broadcasting
}

\author{
NACIYE BERIL EKŞIOGĞLU SARILAR
}

\begin{abstract}
The neo-liberal economic policy that started in the 1970's and made its presence felt after the 1980's has changed the economic and political structures of the World. In this period in which Information Technologies made quick progress, the rapidly shrinking markets and rampant unemployment caused investors to turn their attention towards media. In parallel to the recent economic developments in the 1980's, a commercial approach towards broadcasting surfaced in Turkey. In the era in which commercial broadcasting whose ownership structure was different from the more traditional way of broadcasting was gaining traction, the proprietor and the party in power formed a complicated relationship that pushed back the mentality of public service broadcasting. Although at first it was thought as a place in which the freedom of expression would find voice, as time went on it transformed into a monopoly and failed the expectations of the public. This study focuses on the relationship between private broadcasting and power, the state of public service broadcasting and if it can be a solution for the public in areas such as expression or access to information. In this purpose the role of mass media in the production of hegemonic relationships in a neo-liberal environment is discussed with the focus on neo-liberal economic policies.
\end{abstract}

Keywords: Political economy, Media, Neo-liberalism, Public service broadcasting 